\title{
Goitrogenic/antithyroidal potential of moringa leaves (Moringa oleifera) and spinach (Spinacia oleracea) of Indian origin on thyroid status in male albino rats
}

\author{
Chiranjit Mondal', Amar Kumar Chandra ${ }^{\oplus 1^{*}}$ \\ ${ }^{1}$ Endocrinology and Reproductive Physiology Laboratory, Department of Physiology University of Calcutta, India
}

\begin{abstract}
Moringa leaves and spinach used as vegetables containing cyanogens and polyphenols having suspected antithyroidal activity; however, detailed studies in this aspect found unavailable. Goitrogenic/antithyroid potentiality of those plant foods of Indian origin was evaluated. To explore the goitrogenic/antithyroid effect of those plant foods cyanogenic glucosides, glucosinolates, thiocyanate and polyphenol content were measured. These plant foods were fed with diet regularly to adult male albino rats for 30 and 60 days respectively, followed by evaluation of morphological and functional status of thyroid,as thyroid gland weight, the activity status of thyroid hormone synthesizing enzymes viz. TPO, $\mathrm{Na}^{+}-\mathrm{K}^{+}$-ATPase, deiodinase I, thyroid hormone profiles, thyroid histoarchitecture as well as urinary iodine and thiocyanate. In moringa leaves and spinach fed diet, there was a significant increase in urinary excretion of thiocyanate and iodine, enlargement of thyroid gland along with hypertrophy of thyroid follicles and altered in the activities of thyroid hormone synthesizing enzymes with concomitant changes of thyroid hormone profiles. Effects were more severe in moringa leaves treated group than that of spinach. Biochemical analysis moringa leaves and spinach reveal that those are rich sources of goitrogens and their prolonged consumption gradually developed a relative state of biochemical and morphological hypothyroidism.
\end{abstract}

Keywords: Goitrogen. Hypothyroidism. Iodine. Moringa. Spinach.

\section{INTRODUCTION}

Iodine deficiency is well characterized as the main nutritional risk factor for thyroid dysfunction. Inadequate intake of iodine causes insufficient amount thyroid hormone production, which leads to adverse outcomes of health, termed as iodine deficiency disorders (IDDs) (Zimmermann, Jooste, Pandav, 2008). Iodine deficiency is a major global public health challenge. Universal salt iodisation (USI) is recognised as the most promising and sustainable solution to combat the risk of IDDs at the country level (Global Report, 2009).The use of iodized salt has been introduced and still in practice in India for last few decades to minimise the rate of prevalence of IDDs, but the national programme has experienced major setbacks. Many surveys have been conducted during the post-salt iodisation period throughout the country

\footnotetext{
*Correspondence: A. K. Chandra. Department of Physiology, Faculty of Science, University of Calcutta, 92 APC Road, Kolkata, 700009 - India. Phone: +91 9433161840. E-mail: physiology.ac@gmail.com
}

suggest that factor(s) other than iodine deficiency may be responsible for the persistence of endemic goiter (Chandra et al., 2013).

Regular consumption of plant foods containing goitrogens affect thyroid physiology and may lead to the development of endemic goitre, especially in iodine deficient environments (Delange et al., 1982). The number of plant foods consumed by the people of the country is very large and many of them are reported to have goitrogenic substances, like cyanogenic glucosides, glucosinolates, thiocyanate and polyphenols. Goitrogen containing foods are capable of altering thyroid function by interfering iodide uptake of thyroid tissue or interfering the organification of iodine or inhibiting the activity of thyroid peroxidase that catalyses the reactions for thyroid hormone synthesis (Gaitan, 1990). There are certain plant foods that have goitrogens in different concentrations found to exacerbate the goiter formation in the population having inadequate iodine intake and even in those with adequate iodine intake (Chandra et al., 2004). 
The goitrogenic substances have found to be potentiating to alter thyroid gland morphology and functions. The actual presence or absence of concentration of goitrogenic substances in plant foods do not always represent their true goitrogenic / antithyroid potentiality because the inactive precursors are converted to active goitrogen in the animal body after ingestion (Chandra et al., 2006; Chandra et al., 2015). Therefore, to understand the true goitrogenic / antithyroid activity of suspected plant foods e.g. moringa (Moringa oleifera) and spinach (Spinacia oleracea) require detailed investigation.

However, the goitrogen contents and antithyroidal potential of those plant foods have not been evaluated in vivo earlier. The present study has been conducted to measure the goitrogen content and ascertain the effect of prolonged exposure of those plant foods supplementing adequate iodine on thyroid gland morphology and functional status asevidenced by thyroid gland histology, thyroid peroxidase (TPO) activity, 5'-deiodinase I activity (D1), and $\left(\mathrm{Na}^{+}-\mathrm{K}^{+}\right)$-ATPase activity and assay of serum T4, T3 followed by TSH levels as well as iodine nutritional status in experimental animals and compared with respective control.

\section{MATERIAL AND METHODS}

\section{Animal treatment}

Thirty-two (32) adult (90 \pm 5 days) male albino rats of Wistar strain weighing $150 \pm 10 \mathrm{~g}$ were used in the present study. The animals were maintained as per national guidelines and protocols, approved by the Institutional Animal Ethics Committee (IAEC/PROP/ AC-1/2010 dated 12.08.2010). Control rats were fed with a normal laboratory standardized diet (Chakraborty et al., 2014) as above whereas experimental rats in each group received a normal laboratory diet with one-third of the diet replaced (Mondal et al., 2016) by selected plant foods (viz. moringa leaves and spinach) for 30 and 60 days respectively, obtained from a local markets in Kolkata. Feed consumption, corrected for wasted feed and body weight were measured every seven days. During the last week of the treatment animals in each group were kept in metabolic cages for $24 \mathrm{hr}$ to collect urine over xylene for the analysis of iodine and thiocyanate. At the end of the experimental period the body weights of the rats were recorded and the animals were sacrificed at the end of the 30th and 60th days of the experiment, respectively. Blood samples were collected and serum was separated for hormone assay.

\section{Measurement of thiocyanate}

Thiocyanate content in plant foods was measured following the method of Aldridge (1945) as modified by Michajlovskij and Langer ( 1958). The edible parts of the plant foods were extracted with clean sand and water and the extract containing thiocyanate was treated with trichloroacetic acid, followed by saturated bromine water and arsenous trioxide allowed to react with pyridinebenzidine hydrochloride mixture $(2 \mathrm{~mL}$ of pyridine and $1.6 \mathrm{~mL}$ of $1 \%$ benzedine hydrochloride acidified with $\mathrm{HCl}$ ). The intensity of colour thus developed was measured by a spectrophotometer using $525 \mathrm{~nm}$ wavelength.

\section{Measurement of cyanogenic glucosides}

Cyanogenic glucosides were measured following the method of (Lambert, Ramasamy, Paukstelis, 1975). Moringa leaves and spinach in varying concentration from $10 \mathrm{mg}$ to $1 \mathrm{~g}$ were hydrolysed by the enzyme glucosidase ( $\beta$-glucosidase, Sigma, USA) and the hydrocyanic acid thus liberated was trapped in sodium hydroxide. Cyanide content of trapped hydrocyanic acid was then determined quantitatively in a spectrophotometer of $580 \mathrm{~nm}$ wavelength.

\section{Measurement of glucosinolates}

Glucosinolate was estimated following the procedure of Gmelin and Virtanen (Gmelin, Vitranen, 1960). A methanolic extract of moringa leaves and spinach were prepared and then evaporated in vacuo. The formed residue was then treated with lead acetate followed by $\mathrm{H}_{2} \mathrm{~S}$ to precipitate the excess lead ions present. The filtrate containing glucosinolate was again concentrated in vacuo and treated with myrosinase (thioglucosidase from Sigma, USA) to obtain thiocyanate. Thiocyanate was then estimated by the method of (Aldridge, 1945) as modified by (Michajlovskij, Langer, 1958) as was previously done in the estimation of thiocyanate.

\section{Measurement of total polyphenols}

Total polyphenol content of moringa leaves and spinach were determined by a method described by Matthaus (2002). To summarize, a $0.2 \mathrm{~mL}$ of plant food extract was taken, to which $1 \mathrm{~mL}$ of Folinciocalteau (diluted 10 fold) and $0.8 \mathrm{~mL}$ of $2 \% \mathrm{Na}_{2} \mathrm{CO}_{3}$ was added. The volume was then increased to $10 \mathrm{~mL}$ using water-methanol (4:6) as the diluting fluid. After 
30 mins the absorbance was measured at $740 \mathrm{~nm}$ using a spectrophotometer. The standard curve was prepared using gallic acid standard solutions of known concentrations, and the results were expressed as $\mathrm{mg}$ gallic acid equivalent/g sample.

\section{Thyroid weight}

Just after sacrifice, the rat thyroid glands were dissected and weighed. The relative weight of thyroid gland (mg) was expressed per $100 \mathrm{~g}$ body weight.

\section{Measurement of urinary iodine and thiocyanate}

The urine sample was digested followed by subsequent ashing and iodide was measured by its catalytic action on the reduction of ceric ion $\mathrm{Ce}^{+4}$ to cerous ion $\mathrm{Ce}^{+3}$ (Karmarkar, Pandav, Krishnamachari, 1986) maintaining internal quality control; while thiocyanate concentrations in urine samples were measured using the method of Aldridge (1945) as modified by Michajlovskij and Langer (1958).

\section{Assay of thyroid peroxidase (TPO) activity}

TPO activity in the thyroid of the experimental animals was assayed. TPO activity was measured following $\mathrm{I}_{3}$ from iodide in the presence of $\mathrm{H}_{2} \mathrm{O}_{2}$ in the assay medium following $\Delta \mathrm{OD} / \mathrm{min} / \mathrm{mg} /$ protein in a spectrophotometer (UV-1240 Shimadzu) at a wavelength of $353 \mathrm{~nm}$ using a previously described method (Alexander, 1962).

\section{$5^{\prime}$-deiodinase I (5'-DI) assay}

Iodothyronine 5'-deiodinase type I (5'-DI) activity was measured according to the method of Kodding, Fuhrmann, von zur Mühlen (1986) with slight modifications The activity of 5'-DI was calculated as the difference between the 0 and $30 \mathrm{~min}$ values and expressed in terms of pmoles $\mathrm{T} 3$ formed/mg protein.

\section{Thyroidal $\mathrm{Na}^{+}-\mathrm{K}^{+}$-ATPase assay}

The membrane $\mathrm{Na}^{+}-\mathrm{K}^{+}$-ATPase activity was determined using Ouabin as an inhibitor of the enzyme activity according to the method of Esmann(1988) modified by Sarkar (2002). The enzyme activity was measured following the rate of formation of inorganic phosphate (Pi), a product of ATP hydrolysis. Pi thus formed, reacts with ammonium molybdate in an acidic solution to form phosphomolybdic acid that gives a blue colour. The developed colour is measured at $850 \mathrm{~nm}$ according to the method of Baginski, Foa, Zak (1967).

\section{Protein estimation}

Proteins were estimated by the method of Lowry et al.(1951) using bovine serum albumin (BSA) as the standard protein.

\section{ELISA of serum triiodothyronine $\left(\mathrm{T}_{3}\right)$ and thyroxine $\left(T_{4}\right)$}

Just before sacrifice, blood samples were collected from each rat under ether anaesthesia and the serum was separated for the assay of $\mathrm{T}_{3}$ and $\mathrm{T}_{4}$. All the samples were stored at $-50^{\circ} \mathrm{C}$ prior to measurement. Total serum $\mathrm{T}_{3}$ and $\mathrm{T}_{4}$ were assayed using ELISA kits obtained from RFCL Limited, India (Code no HETT 0318 and HETF 0977 respectively). The sensitivities of the $\mathrm{T}_{3}$ and $\mathrm{T}_{4}$ assays were $0.04 \mathrm{ng} / \mathrm{mL}$ and $0.4 \mathrm{mg} / \mathrm{dl}$, respectively.

\section{ELISA of serum thyroid stimulating hormone (TSH)}

The thyroid stimulating hormone level was assayed employing the quantitative sandwich enzyme immunoassay technique. This hormone level was measured following the manufacturers' protocols using reagents supplied by Cusabio Biotech Limited, Rat TSH kit [Lot no.C0710270665] and the detection ranges of this TSH kit was $0.6 \mu \mathrm{IU} / \mathrm{mL}$ to $24 \mu \mathrm{IU} / \mathrm{mL}$.

\section{Histological study}

Immediately after removal, the thyroid gland of each rat was fixed in $10 \%$ neutral buffered formalin, embedded in paraffin and sections were stained with hematoxylin \& eosin (HE) staining and examined under a light microscope.

\section{Statistical analysis}

Results were expressed as mean \pm standard deviation. One-way analysis of variance (ANOVA) with Tukey's post hoc test was done for statistical evaluation of data and for the determination of level of significance in various groups of animals. In all the cases, a value of $\mathrm{P}<0.05$ was considered as statistically significant. Statistical analyses were performed using Origin 8 and MS-Office Excel 2007 software packages. 
TABLE I - Distribution of cyanogenic glucosides, glucosinolates, thiocyanate and total polyphenols (flavonoids) content in selected plant foods

\begin{tabular}{lcccc}
\hline Plants foods & $\begin{array}{c}\text { Cyanogenic glucosides } \\
\text { (mg/kg wet weight) }\end{array}$ & $\begin{array}{c}\text { Glucosinolates } \\
\text { (mg/kg wet weight) }\end{array}$ & $\begin{array}{c}\text { Thiocyanate } \\
\text { (mg//kg wet weight) }\end{array}$ & $\begin{array}{c}\text { Total polyphenols } \\
\text { (mg of gallic acid eq/gm } \\
\text { dry weight) }\end{array}$ \\
\hline $\begin{array}{l}\text { Moringa leaves } \\
\text { (Moringa oleifera) }\end{array}$ & $2.50 \pm 0.9$ & $7.5 \pm 1.2$ & $174 \pm 8.3$ & $57.4 \pm 7.2$ \\
\hline $\begin{array}{l}\text { Spinach } \\
\text { (Spinacia oleracea) }\end{array}$ & $1.12 \pm 0.5$ & $0.8 \pm 0.3$ & $19 \pm 2.1$ & $13.5 \pm 2.1$ \\
\hline
\end{tabular}

Values are mean \pm SD of 6 observations

\section{Goitrogen content}

The goitrogenic/ antithyroidal content were measured (Table I). Moringa leaves contain highest concentrations of cyanogenic glucosides, glucosinolates, thiocyanate and polyphenols followed by spinach.

\section{Thyroid weight}

Figure 1 shows thyroid weight increased significantly $(\mathrm{p}<0.05)$ after supplementation of selected plant foods (viz. moringa leaves and spinach) for 30 and 60 days when compared with the control groups, 60-day treatment showed more pronounced effect on thyroid weight.

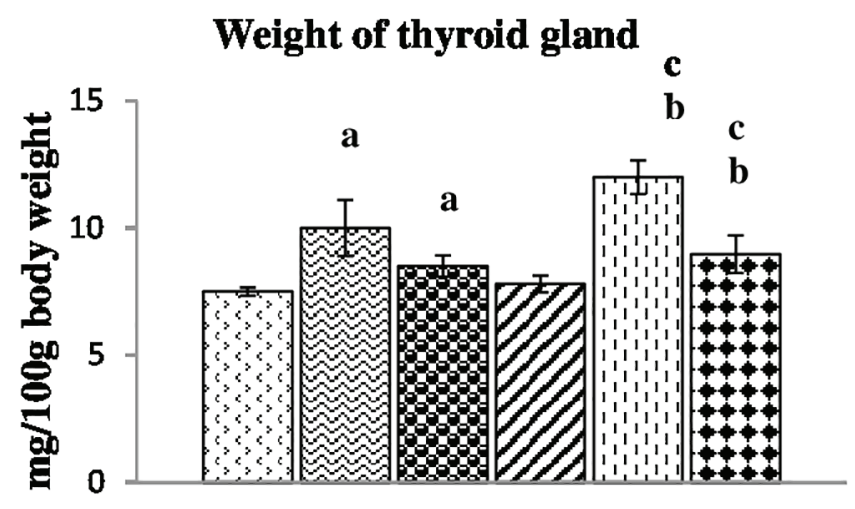

\section{曰Control $30 \mathrm{D}$ Moringa $30 \mathrm{D}$ a Spinach $30 \mathrm{D}$ [a Control $60 \mathrm{D}$ a Moringa $60 \mathrm{D}$ a Spinach $60 \mathrm{D}$}

FIGURE 1 - Changes in the relative thyroid gland weight of rats subjected to moringa leaves and spinach respectevely for 30 days and 60 days. Each bar denotes mesn $\pm \mathrm{SD} ; \mathrm{n}=8$. One-way analysis of cariance (ANOVA) test followed by Tukeys's post hoc test was done to determine differences across means of different groups. Mean values are significantly different by ANOVA at $p<0.05$. ${ }^{\text {a Control }} 30$ days versus treated 30 days group; ${ }^{\mathrm{b} C o n t r o l} 60$ days versus treated 60 days ggroup; ${ }^{\mathrm{c}}$ Treated 30 days versus treated 60 days group.

\section{Urinary iodine and thiocyanate}

Rats fed moringa leaves and spinach for 30 days and 60 days showed significant $(\mathrm{P}<0.05)$ increases in urinary iodine and thiocyanate concentration as compared to their respective controls (Figure 2).

\section{Thyroid peroxidase assay, thyroidal 5'-deiodinase I assay and $\left(\mathrm{Na}^{+}-\mathrm{K}^{+}\right)$-ATPase assay}

Figure 3,4,5 demonstrates thyroid peroxidase activity, thyroidal 5'-deiodinase I (5'-DI) activity and $\left(\mathrm{Na}^{+}-\mathrm{K}^{+}\right)$-ATPase activity that were decreased significantly $(\mathrm{P}<0.05)$ after moringa leaves and spinach administration for 30 and 60 days when compared with the control groups, with the 60-day treatment causing a more pronounced decrease in the enzyme activities were recorded.

\section{Thyroid hormone (T4, T3 and TSH) levels}

The serum T3 and T4 levels were significantly $(\mathrm{P}<0.05)$ decreased in animals after supplementation of moringa leaves and spinach as compared to respective controls.

Like thyroid hormone profiles, significant alteration $(\mathrm{P}<0.05)$ was also noted in serum TSH level in the treated groups as compared to control (Table II).

\section{Morphometric / histometric analysis}

The data in Table III indicates that increase in the areas of both the follicular cells as well as colloid in the treated groups than that of the control group. To understand the relative sizes of colloidal and cellular areas of the thyroid follicles in experimental groups of animal micrometric scale on microphotographs has been fixed.

Semiquantitative assessment of thyroid follicles of control group was shown, mostly to be made up of 


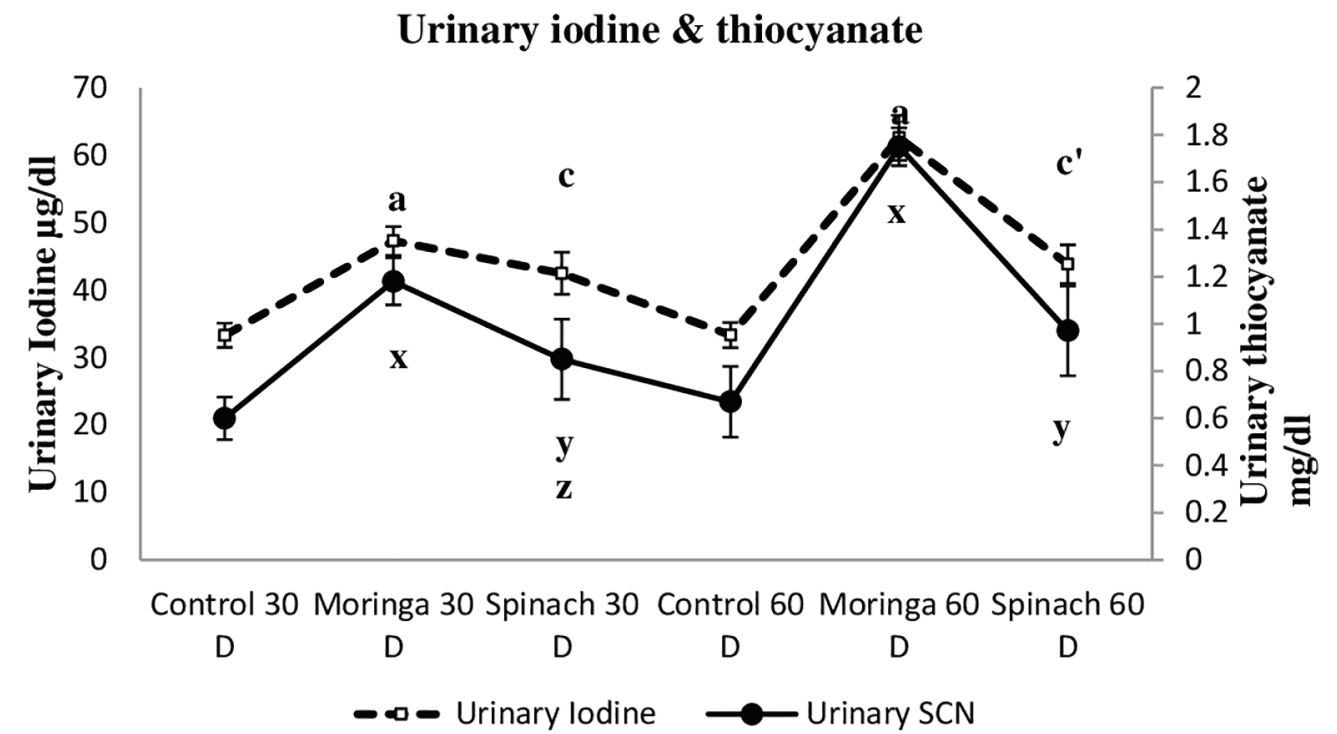

FIGURE 2 - Unirany excretion of iodine and thiocyanate of selected plant foods treated animals for 30 days and 60 days. Each bar denotes mean $\pm \mathrm{SD}, \mathrm{n}=8$. Mean values are significantly different at $\mathrm{p}<0.05$. ${ }^{\mathrm{a}} \mathrm{Control} 30$ days versus moringa 30 days; ${ }^{\mathrm{b}} \mathrm{Control} 30$ days versus spinach 30 days; ${ }^{\circ}$ Moringa 30 days versus spinach 30 days; ${ }^{a}$ Control 60 days versus moringa 60 days, ${ }^{\text {b'Control }} 60$ days versus spinach 60 days; ${ }^{\mathrm{c}}$ Moringa 60 days versuas spinach 60 days; ${ }^{\mathrm{x}} \mathrm{Control} 30$ days versus moringa 30 days; ${ }^{\mathrm{y}} \mathrm{Control} 30$ days versus spinach 30 days; ${ }^{\mathrm{z}}$ Moringa 30 days versus spinach 30 days, ${ }^{{ }^{\prime}} \mathrm{Control} 60$ dyas versus moringa 60 days; ${ }^{{ }^{\prime}}$ Control 60 days versus spinach 60 days; ${ }^{z^{\prime}}$ Morinda 60 days versus spinach 60 dyas.

TPO activity

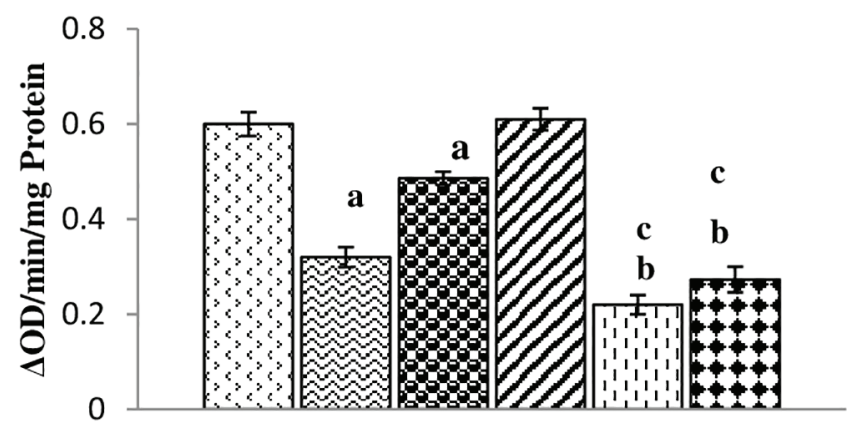

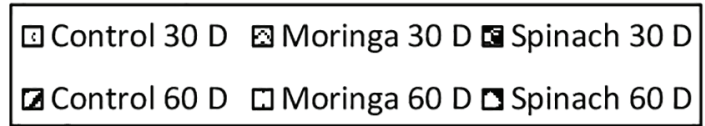

FIGURE 3 - Thyroid peroxidase (TPO) activity of selected plant foods treated animals for 30 days and 60 days respectively. Each pool contained a mixture of three thyroid glands isolated from three individual rats. One-way analysis of variance (ANOVA) test followed by Tukey's post hoc test was done to determine differences across means of different groups. Mean values are significantle different by ANOVA at $p<0.05$. ${ }^{a}$ Control 30 days versus treated 30 days group; ${ }^{\mathrm{b}} \mathrm{Control} 60$ days versus treated 60 days group; 'Treated 30 days versus treated 60 days group.

small and medium sized follicle with a relatively few large follicle while the large and medium sized follicles increased in moringa leaves and spinach fed group of animals in Table III.

\section{5'-deiodinase activity}

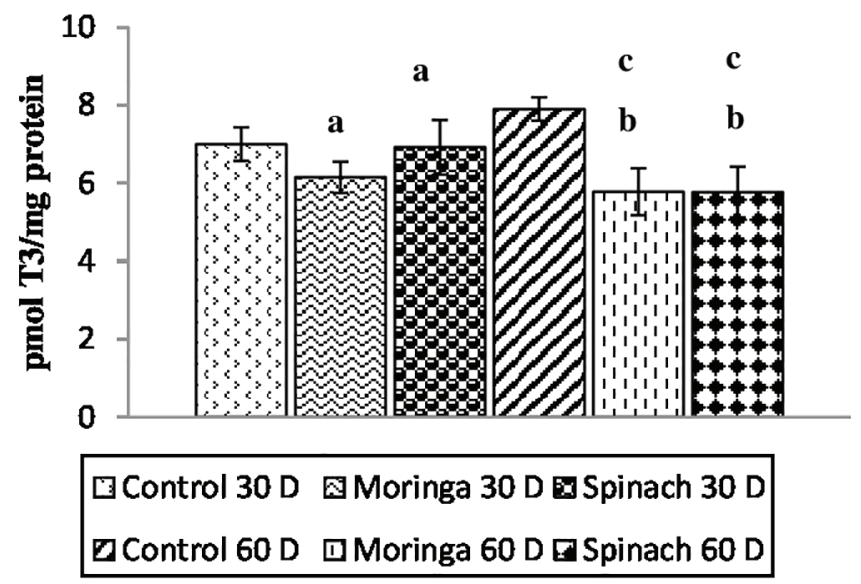

FIGURE 4 - Thyroidal 5'-delodinase I(DI) activity of selected plant foods treated animals for 30 days and 60 days respectively. Each pool contained a mixture of three thyroid glands isolated from three individual rats. One-way analysis of variance (ANOVA) test followed by Tukey's post hoc test was done to determine differences across means of different groups. Mean values are significantly different by ANOVA at $p<0.05$. ${ }^{a}$ Control 30 days versus treated 30 days group; ${ }^{\mathrm{b}} \mathrm{Control} 60$ days versus treated 60 days group; 'Treated 30 days versus treated 60 days group.

\section{Histological studies of thyroid}

In control rats, thyroid follicles were lined by low cuboidal epithelial cells filled with colloid and all the 


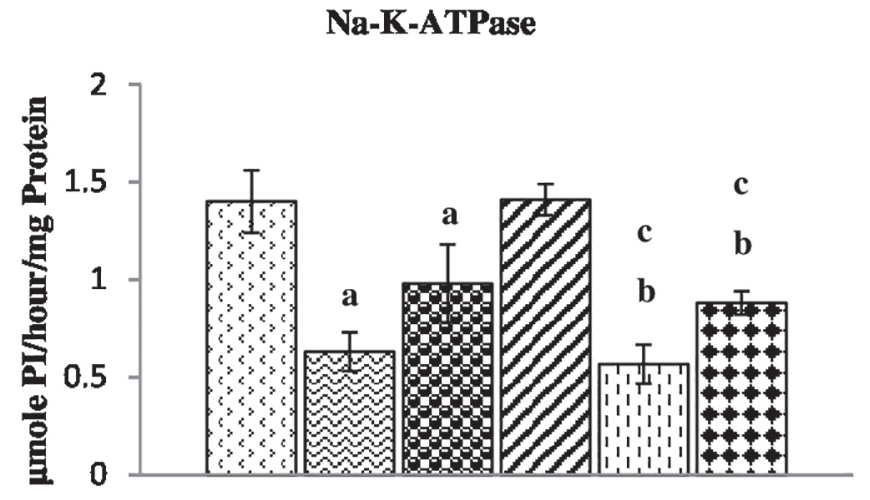

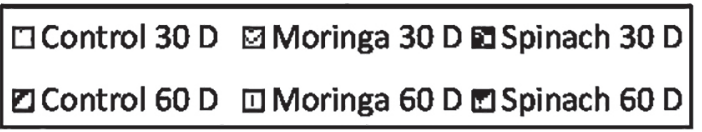

FIGURE 5 - $(\mathrm{Na}+-\mathrm{K}+)$-ATPase activity of selected plant foods trea ted animals for 30 days and 60 days respectevely. Each bar denotes mean $\pm \mathrm{SD}$ of three pooled samples. Each pool contained a mixture of three thyroi glands isolatred from three individual rats. One-way analysis of variance (ANOVA) test followed by Tukey's post hoc test was done to determine differences across means of different groups. Mean values are significantly different by ANOVA at $p<0.05$. ${ }^{\text {a Control }} 30$ days versus treated 30 days group; bControl 60 days versus treated 60 days group; ${ }^{\mathrm{c}}$ Treated 30 days versus treated 60 days group.

follicles were almost equal and regular in size. In the thyroid of the moringa leaves and spinach treated rats, there was an increase in the number of irregularly-shaped follicles filled with relatively less colloid, including hypertrophied and hyperplasic follicular epithelial cells (Plate 1 and 2).

\section{DISCUSSION}

In India and subcontinent the prevalence of iodine deficiency disorders (IDDs) is a common endocrine disorder. To prevent IDDs Government of India has introduced salt iodization policy. In spite of that endemic goitre, the most common manifestation of IDDs is prevalent in many regions possibly for the consumption of cyanogenic and polyphenol / flavonoids containing plant foods. In this investigation two commonly consumed plant foods have been selected that are rich in both cyanogenic and polyphenolic constituents and their anti-thyroidal/ goitrogenic activity were estimated.

The studied plant foods are moringa leaves and spinach which contain both the polyphenols/flavonoids and cyanogen containing cyanogenic glucosides, glucosinolates and thiocyanate in significant proportion. After ingestion the glucosinolates and cyanogenic glucosides are metabolised by various enzymes giving rise to a range of breakdown products viz. isothiocyanates, thiocyanate, oxazolidine-2-thiones etc. Isothiocyanates react spontaneously with amino groups to form thiourea that interfere with organification of iodide and formation of thyroid hormone (Chandra, Ray, 2001).

In this investigation, the weight of the thyroid gland was increased in moringa leaves and spinach fed groups, highest increase in thyroid weight of rats was found fed with moringa leaves for 60 days than in other treated group or controls. The increase in thyroid weight observed in the present study might be due to increased secretion of TSH in the selected plant foods fed groups. Consequently, biochemical hypothyroidism and hypertrophy of the thyroid gland have been evidenced.

Thiocyanate is a degradation product of glucosinolates as well as metabolic end product of cyanogenic glucosides (Conn, 1980). Therefore the increased urinary excretion of thiocyanate in moringa leaves and spinach fed groups of rats as observed was also for the enzymatic degradation of goitrogenic constituents that present in studied plant foods. Thiocyanate, when

TABLE II - Effect of selected plant-foods on total serum triiodothyronine $\left(\mathrm{T}_{3}\right)$, total serum thyroxine $\left(\mathrm{T}_{4}\right)$ and thyroid stimulating hormone (TSH) levels in experimental animals treated for 30 days and 60 days respectively

\begin{tabular}{|c|c|c|c|c|c|c|}
\hline \multicolumn{7}{|c|}{ Treated group } \\
\hline Parameters & $\begin{array}{c}\text { Control } \\
30 \mathrm{D} \\
\end{array}$ & $\begin{array}{c}\text { Moringa leaves } \\
\text { 30 D } \\
\end{array}$ & $\begin{array}{c}\text { Spinach } \\
\text { 30 D } \\
\end{array}$ & $\begin{array}{c}\text { Control } \\
60 \mathrm{D} \\
\end{array}$ & $\begin{array}{c}\text { Moringa leaves } \\
60 \mathrm{D} \\
\end{array}$ & $\begin{array}{c}\text { Spinach } \\
60 \mathrm{D} \\
\end{array}$ \\
\hline $\begin{array}{l}\text { Serum total } \mathrm{T}_{3} \\
(\mathrm{ng} / \mathrm{mL})\end{array}$ & $1.15 \pm 0.03$ & $0.40 \pm 0.017^{\mathrm{a}}$ & $0.74 \pm 0.025^{\mathrm{a}}$ & $1.05 \pm 0.035$ & $0.38 \pm 0.02^{b, c}$ & $0.62 \pm 0.022^{b, c}$ \\
\hline $\begin{array}{l}\text { Serum total } \mathrm{T}_{4} \\
(\mu \mathrm{g} / \mathrm{dL})\end{array}$ & $6.10 \pm 0.46$ & $4.80 \pm 0.32^{\mathrm{a}}$ & $5.60 \pm 0.28^{\mathrm{a}}$ & $5.90 \pm 0.42$ & $4.23 \pm 0.49^{\mathrm{b}, \mathrm{c}}$ & $5.00 \pm 0.25^{\mathrm{b}, \mathrm{c}}$ \\
\hline $\mathrm{TSH}(\mu \mathrm{IU} / \mathrm{mL})$ & $0.142 \pm .004$ & $1.2 \pm 0.046^{\mathrm{a}}$ & $0.206 \pm 0.042^{\mathrm{a}}$ & $0.151 \pm .006$ & $1.36 \pm 0.031^{\mathrm{b}, \mathrm{c}}$ & $0.480 \pm 0.026^{b, c}$ \\
\hline
\end{tabular}

D- Indicates number of days. Data are presented as the mean $\pm \mathrm{SD}, \mathrm{n}=8$. Mean values are significantly different at $p<0.05 .{ }^{\text {a }}$ control 30 day versus treated 30 day group; ${ }^{b}$ control 60 day versus treated 60 day group; ${ }^{c}$ treated 30 day versus treated 60 day group 
TABLE III - Morphometric/ histometric and semiquantitative assessment of thyroid follicles of experimental animals under the influence of selected plant foods fed for 30 days and 60 days

\begin{tabular}{|c|c|c|c|c|c|c|}
\hline \multirow[b]{2}{*}{ Groups } & \multicolumn{6}{|l|}{ Parameters } \\
\hline & $\begin{array}{c}\text { Mean individual } \\
\text { follicular area } \\
\left(\mathbf{m m}^{2}\right)\end{array}$ & $\begin{array}{c}\text { Mean colloidal } \\
\text { area in individual } \\
\text { follicle }\left(\mathbf{m m}^{2}\right)\end{array}$ & $\begin{array}{c}\text { Small } \\
\text { follicles (\%) }\end{array}$ & $\begin{array}{c}\text { Medium } \\
\text { follicles (\%) }\end{array}$ & $\begin{array}{c}\text { Large } \\
\text { follicles (\%) }\end{array}$ & $\begin{array}{l}\text { Immature } \\
\text { follicles (\%) }\end{array}$ \\
\hline Control $30 \mathrm{D}$ & $1.38 \pm 0.02$ & $1.26 \pm 0.05$ & 38.0 & 37.0 & 21.0 & 4.0 \\
\hline $\begin{array}{l}\text { Moringa leaves } \\
30 \mathrm{D}\end{array}$ & $1.50 \pm 0.06^{*}$ & $1.39 \pm 0.07 *$ & 34.0 & 36.0 & 27.0 & 3.0 \\
\hline Spinach 30 D & $1.46 \pm 0.04 *$ & $1.31 \pm 0.03 *$ & 40.0 & 31.0 & 25.0 & 4.0 \\
\hline Control 60 D & $1.40 \pm 0.03$ & $1.27 \pm 0.06$ & 33.0 & 38.0 & 23.0 & 6.0 \\
\hline $\begin{array}{l}\text { Moringa leaves } \\
60 \mathrm{D}\end{array}$ & $1.86 \pm 0.04 *$ & $1.74 \pm 0.05^{*}$ & 32.0 & 33.0 & 33.0 & 2.0 \\
\hline Spinach 60 D & $2.42 \pm 0.02 *$ & $2.25 \pm 0.05^{*}$ & 30.0 & 36.0 & 30.0 & 4.0 \\
\hline
\end{tabular}

Data are presented as the mean $\pm \mathrm{SD}, \mathrm{n}=8$ One-way analysis of variance (ANOVA) test followed by Tukey's post hoc test was to determine differences across means of different groups. Values are asterisk are significantly different by ANOVA at $p<0.05$ when compared to control for 30 days and 60 days. Small follicle, follicular diameter of 5-10 $\mu \mathrm{m}$; medium follicle, follicular diameter of 11-15 $\mu \mathrm{m}$; large follicle, follicular diameter of 16-20 $\mu \mathrm{m}$; and immature follicle, follicular diameter 0-5 $\mu \mathrm{m}$. *Significant differences.
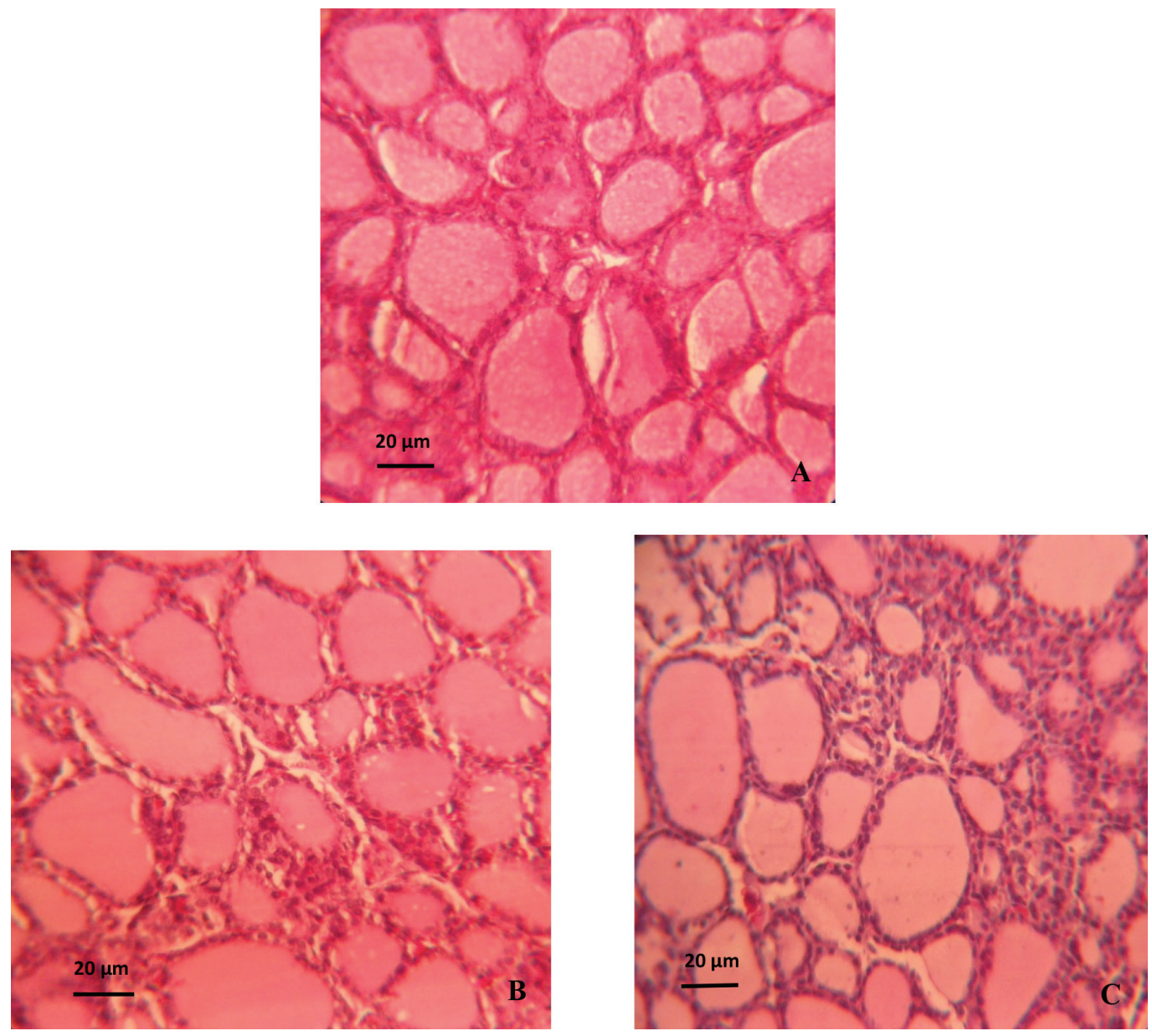

PLATE 1 - Photomicrographs of paraffin-embedded H\&E-stained rat thyroid sections. (A) Rat thyroid section (400X) of control animals for 30 days (scale bar $20 \mu \mathrm{m}$ ). (B) Rat thyroid section $(400 \mathrm{X}$ ) of treated with fresh moringa leaves for 30 days (scale bar $20 \mu \mathrm{m}$ ). (C) Rat thyroid section (400X) of treated with fresh spinach for 30 days (scale bar $20 \mu \mathrm{m}$ ). 

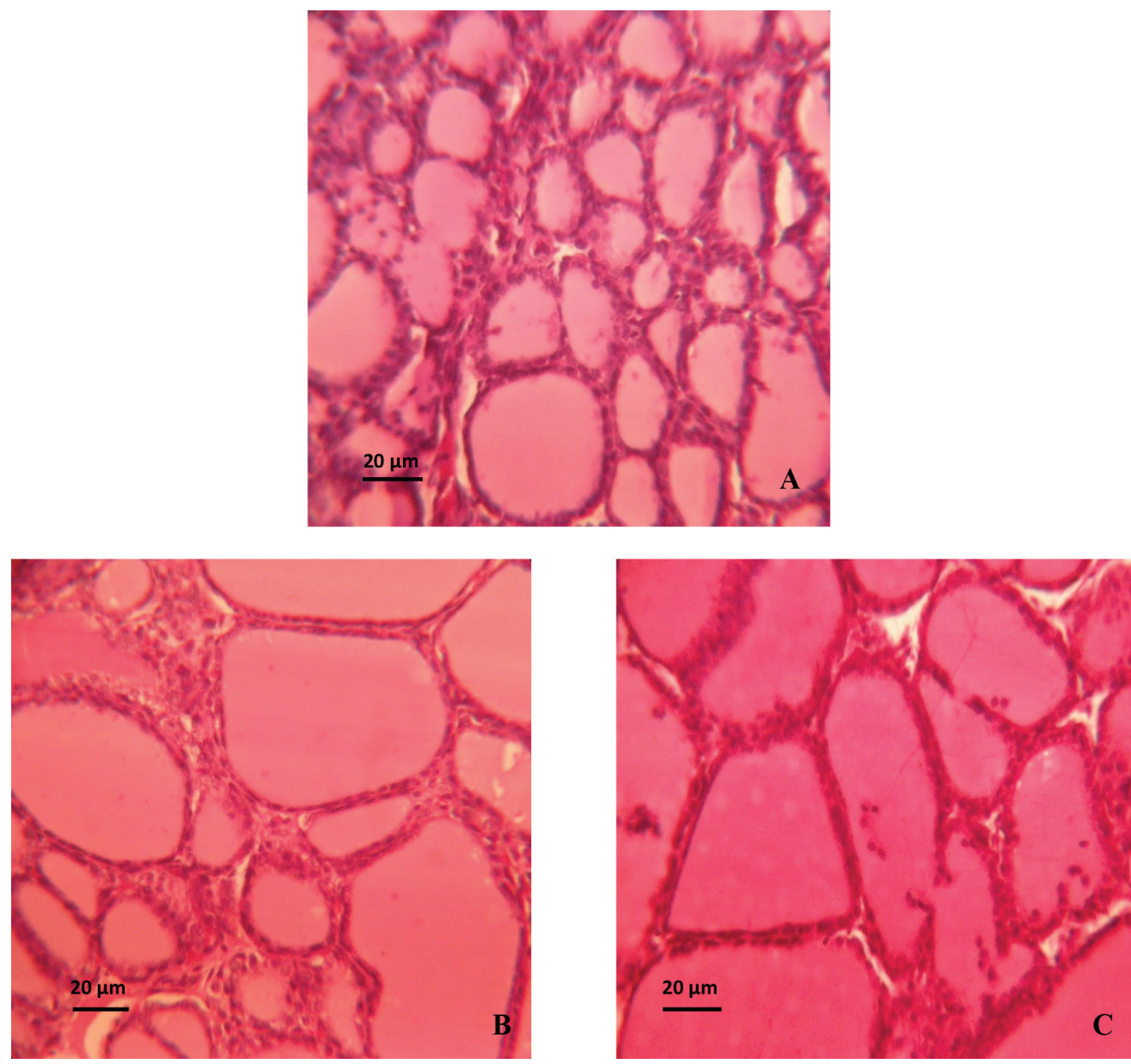

PLATE 2 - Photomicrographs of paraffin-embedded H\&E-stained rat thyroid sections. (A) Rat thyroid section (400X) of control animals for 60 days (scale bar $20 \mu \mathrm{m}$ ). (B) Rat thyroid section $(400 \mathrm{X}$ ) of treated with fresh moringa leaves for 60 days (scale bar $20 \mu \mathrm{m})$. (C) Rat thyroid section (400X) of treated with fresh spinach for 60 days (scale bar $20 \mu \mathrm{m}$ ).

present in excess concentration, also stimulates the efflux of iodide from thyroid gland that results in an increased excretion of iodine in urine (Ermans, Bourdoux, 1989). Therefore, thiocyanate present in those plants had increased the urinary excretion of iodine in moringa leaves and spinach fed groups of rats as observed.

Flavonoids are the most abundant polyphenols in human diet, representing about $2 / 3$ of all those ones ingested. More than 8000 phenolic structures are currently known, and among them over 4000 flavonoids have been identified (Harborne, Williams, 2000; Cheynier, 2005). It has been reported that quercetin and resveratrol both are able to inhibit thyroid function and decreases the expression of the main thyroid-restricted genes involved in thyroid hormone synthesis and it is relevant in subjects with goiter and/or subclinical thyroid dysfunction (Giuliani et al., 2014; Giuliani et al.,2017).The findings of this study suggest that moringa leaves and spinach both have shown potent anti thyroidal activity due to presence of polyphenols in addition to thiocyanate.
Hypo/hyper functioning of thyroid gland or more specifically, thyroid hormone level, is related with the activity status of three key enzymes of the thyroid hormone biosynthetic pathway, viz., TPO, $\mathrm{Na}^{+}-\mathrm{K}^{+}$-ATPase and 5 '-deiodinase (DI). Changes in the activity status of these three enzymes result in tremendous alterations in thyroid morphology and function.

It is found that thyroid peroxidase activity and DI activity were decreased in treated group of rats. Flavonoids inhibit TPO activity in vitro (Chandra, De, Choudhury, 2011) which seems to be competitive and it might be able to scavenge $\mathrm{H}_{2} \mathrm{O}_{2}$, an essential TPO cofactor (Divi, Doerge, 1996). A high concentration of thiocyanate is also responsible for inhibition of TPOcatalysed oxidation (I- leads to $\mathrm{I}_{2}$ ) (Virion et al., 1980). It has been evidenced that green tea, black tea and natural plant-derived flavonoids seem to inhibit DI activity in vivo (Chandra et al., 2015).It has been reported that chronic consumption of polyphenols responsible for decreased D1 activity, which is turn change the 
concentration of $\mathrm{T}_{3}, \mathrm{~T}_{4}$ and TSH levels in circulation (Chandra et al., 2015).

The follicular epithelium of the thyroid gland is no exception, and the iodine required for hormone biosynthesis is accumulated within the gland through the combined actions of the $\mathrm{Na}^{+}-\mathrm{K}^{+}$-ATPase and the $\mathrm{Na}^{+}-\mathrm{I}^{-}$ co-transporter (Dai, Levy, Carrasco, 1996).NIS-mediated iodide transport is inhibited by ouabain as well as by the competitive inhibitors thiocyanate and perchlorate (Spitzweg, Morris, 2002) and is stimulated by TSH. The most important finding in this study is that moringa leaves and spinach contain cyanogenic glucosides and glucosinolates metabolised and converted into thiocyanate and isothiocyanate that inhibited $\left(\mathrm{Na}^{+}-\mathrm{K}^{+}\right)$-ATPase activity which might have impaired the iodine concentrating mechanism in thyroid gland and leads to deregulation of thyroid hormone biosynthesis.

Another finding is the decreased serum T3, T4 levels and elevated level of TSH in the treated groups as compared to controls were associated with inhibition of TPO, 5'-deiodinase (DI) and $\mathrm{Na}^{+}-\mathrm{K}^{+}$-ATPase activity of the thyroid gland under the influence of goitrogen/ antithyroid agents present in moringa leaves and spinach. Inhibition of both iodide uptake and thyroidal iodide efflux due to excess thiocyanate (Mondal et al., 2016) and polyphenols might be another reason for the reduced synthesis of thyroid hormones.

Morphometric / histometric analysis of the thyroid glands showed increase in the area of the follicular cells as well as colloid following moringa leaves and spinach treatment. Thyroid follicles also revealed the presence of relatively more numbers of large and medium sized follicles in the moringa leaves and spinach treated experimental animals while the control animals showed the presence of small sized follicles. Gaitan and Dunn (1992) also reported the colloid in the follicles was found to take up more eosin for the lack of iodine indicating development of hypothyroidism. Decreased level of circulating thyroid hormones in the blood results in increased release of thyroid stimulating hormone by the anterior pituitary gland. These results are clearly indicative of TSH-induced hypertrophic and hyperplastic changes in the thyroid gland under the influence of studied plant foods containing goitrogens of different origin (Plate 1and 2). Recent studies demonstrated that the activation of cAMP signal (cyclic adenosine monophosphate) in thyrocytes mediates the development of mitotic activity (Roger et al., 1988). The induction of cAMP cascade demonstrated the increase proliferative activity of thyroid epithelial cells in mice in vivo (Ledentet al., 1992) and in vitro (Ivan et al., 1997).

\section{CONCLUSION}

Of the studied plant foods the anti-thyroid/ goitrogenic potency of moringa leaves was found to be higher than spinach. Regular and prolonged exposure in substantial amount of those plant foods containing goitrogens of diverse nature progressively modify the activities of thyroid hormone synthesizing enzymes, that act both at the cellular and molecular levels which have been reflected in altered thyroid hormone profiles, that in turn, brought about the modifications of histoarchitecture in the thyroid developing a state of biochemical as well as morphological hypothyroidism. The etiological factors underlying this phenomenon are not only cyanogenic glucosides, glucosinolates, thiocyanate but also polyphenol.

\section{ACKNOWLEDGMENTS}

The financial assistance by Rajiv Gandhi National Fellowship Scheme, University Grants Commission (UGC), New Delhi, to Chiranjit Mondal is gratefully acknowledged.

\section{REFERENCES}

Aldridge WN. The estimation of micro quantities of cyanide and thiocyanate.Analyst. 1945;70:474-75.

Alexander NM. A spectrophotometer assay of iodine oxidation by thyroid peroxidase.Anal Biochem.1962;4(4):341-45.

Baginski ES, Foa PP, Zak B. Determination of phosphate: study of labile organic phosphate interference. ClinChim Acta. 1967;15(1):155-58.

Chakraborty A, Mondal C,Sinha S, Mandal J, Chandra AK. Amiodarone induced oxidative stress in stress - vulnerable organs of adult male rats. Asian J Pharm Clin Res. 2014;7(4):177-183.

Chandra AK, Lahari D, Mukhopadhyay S, Tripathy S. Effect of cassava (Manihot esculenta crentz) on thyroid status under conditions of varying iodine intake in rats.AJTCAM. 2006;3(3):87-99.

Chandra AK, Mukhopadhyay S, Lahari D, Tripathy S. Goitrogenic content of cyanogenic plant foods of Indian origin and their in vitro anti-thyroidal activity. Indian J Med Res. 2004;119(5):180-185. 
Chandra AK, Mondal C, Sinha S, Chakraborty A, Pearce EN. Synergic actions of polyphenols and cyanogens of peanut seed coat (Arachis hypogaea) on cytological, biochemical and functional changes in thyroid. Indian J Exp Biol. 2015;53(3):14351.

Chandra AK, Ray I. Dietary supplies of iodine and thiocyanate in the etiology of endemic goitre in Tripura. Ind $\mathbf{J}$ Pediatr.2001;68(5):399-04.

Chandra AK, De N, Choudhury SR. Effect of different doses of un-fractionated green and black tea extracts on thyroid physiology. Hum Exp Toxicol. 2011;30(8):884-96.

Chandra AK, Singh LH, Ghosh S, Pearce EN. Role of bambooshoot in the pathogenesis of endemic goiter in Manipur, North East India.EndocrPract. 2013;19(1):36-45.

Cheynier V. Polyphenols in foods are more complex than often thought. Am J Clin Nutr. 2005;81(1 Suppl):223S-229S.

Conn EE. Cyanogenic compounds. Ann Rev Plant Physiol. 1980;31:433-51.

Dai G, Levy O, Carrasco N. Cloning and characterization of the thyroid iodide transporter. Nature.1996;379(6564):458-60.

Delange F, Bourdoux P, Colinet E, Courtois P, Hermart P, Lagasse R. Nutritional factors involved in the goitrogenic action of cassava, Cassava toxicity and thyroid research and public health issues. Ottawa, Canada: International Development Research Centre (IDRC-207e); 1982. p.17.

Divi RL, Doerge DR. Inhibition of thyroid peroxidase by dietary flavonoids.Chem Res Toxicol.1996;9(1):16-23.

Ermans AM,Bourdoux P. AntithyroidSulfurated Compounds. In: Gaitan E. (Editor).Environmental Goitrogens. Boca Raton, FL:CRC Press; 1989; p. 15-31.

Esmann M. ATPase and phosphate activity of $\left(\mathrm{Na}^{+}-\mathrm{K}^{+}\right)$-ATPase: molar and specific activity, protein determination. Methods Enzymol. 1988;156:5-15.

Gaitan E, Dunn JT. Epidemiology of iodine deficiency.Trends Endocrinol Metab. 1992;3(5):170-175.

Gaitan E. Goitrogens in food and water.Annu Rev Nutr. 1990;10:21-39.
Global Report. The Micronutrient Initiative Investing in the Future: A United Call to Action on Vitamin and Mineral Deficiencies. Global Report 2009. Available at: http://www. unitedcalltoaction.org/documents/Investing_in_the_future.pdf.

Gmelin R, Vitranen AI. The Enzymatic formation of thiocyanate $(\mathrm{SCN})$ from precursors in Brassica species.Acta Chem Scand. 1960;14(2):507-512.

Giuliani C, Bucci I, DiSanto S, Rossi C,Grassadonia A, Piantelli M,et al. The flavonoid quercetin inhibits thyroidrestricted genes expression and thyroid function. Food Chem. Toxicol.2014;66:23-29.

Giuliani C, Manuela I, Laura C, Hysi A, Bucci I, DiSanto S,et al. Resveratrol has anti-thyroid effects both in vitro and in vivo. Food Chem. Toxicol.2017;107(Pt a):237-247.

Harborne JB, Williams CA. Advances in flavonoid research since 1992. Phytochemistry. 2000;55(6):481-504.

Ivan M, Ludgate M, Gire V, Bond JA, Wynford-Thomas D. An amphotropic retroviral vector expressing a mutant gsponcogene: effects on human thyroid cells in vitro.J Clin Endocrinol Metab. 1997;82(8):2702-2709.

Karmarkar MG, Pandav CS, Krishnamachari KAVR. Principle and procedure for iodine estimation-A laboratory manual. New Delhi, India: Indian Council of Medical Research; 1986.

Kodding R, Fuhrmann H, von zur Mühlen A. Investigations on Iodothyronine deiodinase activity in the maturing rat brain.En docrinology.1986;118(4):1347-52.

Lambert JL, Ramasamy J, Paukstelis JV. Stable reagents for the colorimetric determination of cyanide modified koning reaction. Anal Chem. 1975;47(6):916-18.

Ledent C, Dumont JE, Vassart G, Parmentier M. Thyroid expression of an $\mathrm{A} 2$ adenosine receptor transgene induces thyroid hyperplasia and hyperthyroidism. EMBO J. 1992;11(2):537-42.

Lowry OH, Rosenbrough NJ, Farr AL, Randall RJ. Protein measurement with the folin phenol reagent. J Biol Chem. 1951;193(1):265-75.

Matthaus B. Antioxidant activity of extracts obtained from residues of different oilseeds. J Agri Food Chem. 2002;50(12):3444-52. 
Michajlovskij N, Langer P. Studien uber Benziehungen zwischen Rhodanbildung und Kropfbildender Eigenschaft von Nahrungsmitteln. in: Gehalt einiger Nahrungs mittel and praformierten Rhodanid. ZPhysiol Chem.1958;312:26-30.

Mondal C, Sinha S, Chakraborty A, Chandra AK. Studies on goitrogenic/ antithyroidal potentiality of thiocyanate, catechin and after concomitant exposure of thiocyanate-catechin.IJPCR. 2016;8(1):108-16.

Roger P, Taton M, Van Sande J, Dumont JE.Mitogenic effects of thyrotropin and adenosine 3', 5'-monophosphate in differentiated normal human thyroid cells in vitro.J Clin Endocrinol Metab. 1988;66(6):1158-65.
Sarkar PK. A quick assay for $\mathrm{Na}^{+}-\mathrm{K}^{+}$-ATPase specific activity.Z Naturforsch. 2002;57(5-6):562-64.

Spitzweg C, Morris JC. Sodium Iodide Symporter (NIS) and Thyroid.Hormones. 2002;1(1):22-34.

Virion A, Deme D, Pommier J, Nunez J. Opposite effect of thiocyanate on tyrosine iodination and thyroid hormone synthesis.Eur J Biochem. 1980;112(1):1-7.

Zimmermann MB, Jooste PL, Pandav CS. Iodine deficiency disorders.Lancet.2008;372(9645):1251-62.

Received for publication on $09^{\text {th }}$ January 2018 Accepted for publication on $09^{\text {th }}$ August 2018 